\title{
Correction to: Intradermal acupuncture for rheumatoid arthritis: study protocol for a randomised controlled trial
}

Huifang Luo ${ }^{1}$, Jie Peng ${ }^{1}$, Qing Ma ${ }^{1}$, Zhihua Wei ${ }^{1}$, Changsong Lin' ${ }^{1}$, Mingying Zhang ${ }^{1}$, Peiwu Li ${ }^{2}$, Yang Song ${ }^{1 *}$ and Xiangwei Yang ${ }^{1 *}$

\section{Correction to: Trials 22, 450 (2021) \\ https://doi.org/10.1186/s13063-021-05416-0}

Following the publication of the original article [1], the authors notified us that the affiliation for Peiwu $\mathrm{Li}$ should remain the Department of Spleen and Stomach Diseases... (affiliation number 2). However, this affiliation should be removed for for Mingying Zhang, Changsong Lin and Xiangwei Yang, as it was mistakenly added during proofs. The correct affiliation for Mingying Zhang, Changsong Lin and Xiangwei Yang should be affiliation number 1.

The original article has been corrected.

\section{Author details}

'School of Nursing, Guangzhou University of Chinese Medicine, Guangzhou 510405, Guangdong Province, China. ${ }^{2}$ Department of Spleen and Stomach Diseases, The First Affiliated Hospital of Guangzhou University of Chinese

Medicine, Guangzhou 510405, Guangdong Province, China.

Published online: 12 August 2021

\section{Reference}

1. Luo, et al. Intradermal acupuncture for rheumatoid arthritis: study protocol for a randomised controlled trial. Trials. 2021;22:450. https://doi.org/10.1186/ s13063-021-05416-0.

The original article can be found online at https://doi.org/10.1186/s13063021-05416-0.

* Correspondence: fau20@126.com; 1327758056@qq.com

${ }^{1}$ School of Nursing, Guangzhou University of Chinese Medicine, Guangzhou 510405, Guangdong Province, China

Full list of author information is available at the end of the article

(c) The Author(s). 2021 Open Access This article is licensed under a Creative Commons Attribution 4.0 International License, which permits use, sharing, adaptation, distribution and reproduction in any medium or format, as long as you give appropriate credit to the original author(s) and the source, provide a link to the Creative Commons licence, and indicate if changes were made. The images or other third party material in this article are included in the article's Creative Commons licence, unless indicated otherwise in a credit line to the material. If material is not included in the article's Creative Commons licence and your intended use is not permitted by statutory regulation or exceeds the permitted use, you will need to obtain permission directly from the copyright holder. To view a copy of this licence, visit http://creativecommons.org/licenses/by/4.0/. The Creative Commons Public Domain Dedication waiver (http://creativecommons.org/publicdomain/zero/1.0/) applies to the data made available in this article, unless otherwise stated in a credit line to the data. 